\title{
PENGARUH KOMPETENSI APARATUR DESA DAN PEMAHAMAN AKUNTANSI DESA SEBONG LAGOI KECAMATAN TELUK SEBONG BINTAN
}

\section{Effect of Official Competency and Accounting Knowledge at Sebong Lagoi Village, Teluk Sebong, Bintan}

\author{
Nurhasanah $^{1 *}$, Asri Eka Ratih ${ }^{1}$ \\ 1)Jurusan Manajemen, Fakultas Ekonomi, Universitas Maritim Raja Ali Haji, Tanjungpinang \\ *Korespondensi : ana08.sws@gmail.com
}

\begin{abstract}
ABSTRAK
Pengabdian ini bertujuan untuk mengetahui dan mengukur tingkat kompetensi aparatur dan pemahaman desa sebagai laporan keuangan desa dalam pengelolaan dana desa agar lebih berkualitas dan sesuai dengan standar. Hasil dari pengabdian ini diharapkan nantinya dapat dijadikan salah satu tolak ukur keberhasilan serta mempertanggung jawabkannya dengan kompetensi yang dimiliki aparatur desa serta pemahaman akuntansi desa. Pengabdian ini dilakukan di desa Teluk Sebong Bintan, Hasil dari pengabdian ini menjelaskan bahwa semakin tinggi kompetensi yang dimiliki oleh aparatur desa, maka akan semakin baik kualitas laporan keuangan yang disajikan
\end{abstract}

Kata Kunci : Kompetensi, Pemahaman Akuntansi, Pengabdian Masyarakat

\begin{abstract}
This service is used to find out and measure the level of apparatus and understand the village as a village financial report in managing village funds to be of higher quality and in accordance with standards. The results of this service are expected to be used as a measure of success and accountable for responsibility with qualifications issued in the village and village tax. This service was carried out in Teluk Sebong Bintan village. The results of this service explained that the higher issued by the village apparatus, the better the quality of the financial statements presented.
\end{abstract}

Keywords: Competence, Understanding of Accounting, Community Service

\section{PENDAHULUAN}

Keberhasilan penyelenggaraan pemerintahan di dalam suatu masyarakat akan turut di tentukan oleh para pemimpin masyarakat dan didukung oleh peran serta masyarakat maka demikian pula pada penyelenggaran pemerintahan di desa memerlukan kemampuan dari pemimpin dan didukung oleh masyarakat desa setempat. Dalam rangka mewujudkan tujuan nasional sebagaimana tertuang dalam Undang-undang dasar 1945, pemerintah memberikan perhatian terhadap penyelenggaraan pemerintahan di desa.

Perhatian yang besar terhadap pedesaan itu didasarkan pada kenyataan bahwa desa merupakan tempat berdiamnya sebagian besar rakyat Indonesia, kedudukan desa dan masyarakat desa merupakan dasar landasan kehidupan bangsa dan negara Indonesia. Salah satu unsur penting yang 
mendesak untuk segera dipersiapkan dalam kaitannya dengan pelaksanaan otonomi desa adalah aparat pemerintah desa yang memiliki kemampuan atau kompetensi yang memadai guna mendorong peningkatan kinerja pemerintahan yang selama ini terkesan masih relatif rendah. Rendahnya kinerja aparat pemeintah desa diindikasikan dengan masih banyaknya tuntutan dan keluhan masyarakat terhadap kualitas pelayanan yang diberikan, seperti pengurusan surat-surat kependudukan, surat-surat tanah, keterangan lahir dan lainlain.

Laporan penggunaan dan pengelolaan dana desa adalah salah satu bentuk laporan pertanggungjawaban pengelola desa, laporan pertanggungjawaban dari pengelolaan dana desa itu sendiri harus disajikan secara transparan dan akuntabel. Dalam penyusunan laporan pertanggungjawaban penggunaan dan pengelolaan dana desa harus disesuaikan dengan standar dan aturan akuntansi yang telah ditetapkan. Akuntansi desa adalah pencatatan dari proses transaksi yang terjadi di desa, dibuktikan dengan notanota kemudian dilakukan pencatatan dan pelaporan keuangan sehingga akan menghasilakan informasi dalam bentuk laporan keuangan yang akan digunakan pihak-pihak yang berhubungan dengan desa.

Keberhasilan atau kegagalan penyelenggaraan pemerintahan desa sangat ditentukan oleh kompetensi kepala desa, baik kompetesi pengetahuan, kompetensi keterampilan, maupun kompetensi sikap. Maka dari itu untuk mewujudkan pemerintahan dan pengelolaan dana desa yang profesional dan partisipatif, perlu dilakukannya peningkatan kompetensi aparatur desa dalam pengelolaan dana dan akuntansi desa melalui program pengabdian kepada masyarakat dalam bentuk penyuluhan Peningkatan Kompetensi Aparatur Desa dan Pemahaman Akuntansi Desa Sebong Lagoi, Kecamatan Teluk Sebong Bintan

\section{METODE}

\section{Waktu dan Tempat}

Kegiatan dilaksanakan pada tanggal 2 September 2018 bertempat di Balai Desa Sebong Lagoi, Kecamatan Teluk Sebong, Kabupaten Bintan.

\section{Prosedur Pelaksanaan dan Analisis Data}

Metode yang digunakan pada kegiatan ini dibagi kepada tiga tahapan, yaitu tahap persiapan, pelaksanaan dan evaluasi.

\section{Persiapan awal}

Pada tahap ini dilakukan survey awal lokasi, mempelajari dinamika kemampuan aparatur desa serta pemahaman Akuntansi Desa tahun 2017 baik yang berhasil mapun yang belum, melakukan penawaran untuk membantu memberikan pembekalan/pengetahuan melalui program pengabdian kepada masyarakat, menetapkan lokasi, audiensi dan tempat kegiatan, serta menerbitkan dokumen kerjasama.

\section{Pelaksanaan program}

Kegiatan dilaksanakan melalui penyampaian informasi yang berkaitan dengan, "Peningkatan Kompetensi Aparatur Desa Dan Pemahaman Akuntansi Desa Sebong Lagoi" Selain materi tersebut juga disampaikan materi motivasi membangun desa yang di harapkan dapat memberikan motivasi agar Desa Sebong Lagoi mampu menjadi desa mandiri.

\section{Tahap evaluasi}

Tahapan evaluasi ada dua kategori, yaitu evaluasi efektivitas dari kegiatan tersebut dan impact yang di berikan dari kegiatan tersebut terhadap peserta. Hasil dapat diperoleh melalui informasi, komunikasi dan interaksi secara berkala.

\section{HASIL DAN PEMBAHASAN}

$\begin{array}{cll}\text { Kagiatan } & \text { sosialisasi } & \text { "Peningkatan } \\ \text { Kompetensi } & \text { Aparatur } & \text { Desa }\end{array}$


Pemahaman Akuntansi Desa Sebong Lagoi" telah dilaksanakan dengan peserta yang berasal dari aparatur desa Sebong Lagoi. Pesera kegiatan ini antara lain perangkat desa, petugas pengelola dana desa, unsur organiasi PKK, karang taruna, dan tokoh masyarakat. Acara berlangsung dengan baik dan lancar banyak hal kebijakan-kebijakan yang berkaitan dengan pengelolaan dana desa yang harus di jelaskan dan di sederhanakan agar pengelolaannya benar-benar dirasakan manfaatnya oleh masyarakat.

Kompetensi berdasarkan kamus inggrisindonesia disebut dengan competence yaitu suatu kemampuan atau kecakapan (Wojowarsito dan Poerwadaminta, 2000). Mitrani et al. (2002) mengatakan bahwa kompetensi adalah sifat dasar seseorang yang dengan sendirinya berkaitan dengan pelaksanaan suatu pekerjaan secara efektif dan berhasil.

Menurut Mitrani et al. (2002) bahwa kompetensi mengandung dua pengertian atau makna, yaitu :

(1) Bidang kemampuan pengetahuan dan keterampilan yang dapat diperoleh melalui proses belajar (pendidikan, pelatihan, dan pengalaman). Kemampuan tersebut mencakup pengetahuan konseptual (seringkali kejuruan dan keahlian), dan sejumlah besar kegiatan kerja generik (seperti: menentukan sasaran, membuat rencana, memberikan penyajian/presentase), dan lain-lain.

(2) Kompetensi-kompetensi yang merupakan perangai, motif atau sifat-sifat yang tertanam lebih dalam pada diri seseorang, misalnya : rasa percaya diri, daya tahan terhadap tekanan/ketegangan, keinginan untuk berprestasi, dan lain-lain. Sudarmanto, (2009) mengatakan, kompetensi merupakan karakteristik dasar perilaku individu yang berhubungan dengan kriteria acuan efektif dan atau kinerja unggul di dalam pekerjaan atau situasi. Armstrong (2004) mengartikan kompetensi adalah apa yang orang bawa pada suatu pekerjaan dalam bentuk tipe dan tingkat-tingkat perilaku yang berbeda.

Pemahan akuntansi Desa Dengan dikeluarkannya Undang-Undang tentang Desa maka bersamaan dengan itu pemerintahan desa akan mendapatkan dana untuk membiayai pemeritahan desa itu sendiri, dengan demikian pemerintahan desa juga memiliki kewajiban untuk mengelola dana desa dan melaporkan penggunaan dana desa yang telah diberikan dalam bentuk laporan keuangan atas pengelolaan dana desa tersebut. Laporan pertanggungjawaban itu sendiri berpedoman pada Permen Nomor 113 Tahun 2014.

Untuk menyusun laporan keuangan itu sendiri pemerintahan desa yang dikelola oleh aparatur desa yang telah dipilih sedikit banyaknya harus memahami akuntansi desa. Akuntansi desa adalah pencatatan yang dimulai dari proses transaksi yang terjadi di desa, dibuktikan dengan nota-nota, yang kemudian dilakukan pencatatan dan pelaporan keuangan sehingga akan menghasilkan informasi dalam bentuk laporan keuangan yang digunakan pihak-pihak yang berhubungan dengan desa.

Bendahara sebagai penyusun laporan keuangan dan kepala desa sebagai penanggungjawab penggunaan dan pengelolaan dana desa, hendaknya dapat memahami tentang akuntansi dan isi dari laporan keuangan yang merupakan bentuk dari laporan pertanggungjawabkan, sehingga informasi yang dituangkan dan terdapat dalam laporan pertanggungjawaban itu dapat digunakan sebagai sarana penyampaian informasi kepada masyarakat.

Minimnya pengetahuan dan pemahaman akan akuntansi dan pelaporan untuk desa dapat menimbulkan permasalahan. Hal tersebut memang masih terbuka lebar hingga saat ini. Namun demikian, pemerintah desa tetap dituntut untuk melakukan penatausahaan keuangan desa dan mempertanggungjawabkan sesuai 
dengan kaidah yang berlaku. Jika hal ini tidak mereka penuhi, tentunya para akuntan pun akan mengalami kesulitan dalam membantu dan mengawal akuntansi dan pelaporan keuangan desa.

\section{KESIMPULAN}

Kegiatan Peningkatan Kompetensi Aparatur Desa Dan Pemahaman Akuntansi Desa Sebong Lagoi membutuhkan koordinasi yang lebih intensif dan waktu yang cukup. Kebijakan pemerintah setempat tentang kompetensi aparatur desa dan pemahaman akuntansi Desa Sebong Lagoi yang sifatnya akuntabilitas perlu dikelola dengan hati-hati. Minimnya pemahaman perangkat pengelola dana desa akan arti pentingnya informasi dan mekanisme pengelolaan yang harusnya didapatkan dari pihak luar seperti melalui kegiatan pengabdian kepada masyarakat.

\section{DAFTAR PUSTAKA}

Armstrong, M. 2004. Performance Management, terjemahan, Yogyakarta, Tugu Publesher..

Mitrani, A. et al. 2002. Manajemen Sumber Daya Manusia Berdasarkan Kompetensi, Terjemahan, Jakarta. Intermedia.

Permendagri No. 113 Tahun 2014 tentang Pengelolaan Keuangan Desa

Sudarmanto, (2009). Kinerja dan Pengembangan Kompetensi SDM, Teori, Dimensi, Pengukuran, dan Impelementasi dalam Organisasi. Yogyakarta: Pustaka Pelajar.

Undang-Undang Nomor 6 Tahun 2014 tentang Desa

Diterima : 5 September 2018

Disetujui : 8 November 2018 